\title{
LITERACKIE WIZJE ŻYCIA ROZUMNEGO W KOSMOSIE I ICH KONSEKWENCJE METAFIZYCZNE, EPISTEMOLOGICZNE I AKSJOLOGICZNE
}

\begin{abstract}
Streszczenie. Literatura fantastycznonaukowa od dziesięcioleci kreśli wizje życia rozumnego na innych planetach. Rodzą się oczywiste pytania: czy możliwe jest porozumienie z intelektem rozwiniętym w skrajnie różnym od ludzkiego środowisku, wyposażonym być może w odmienną percepcję, odmienne sposoby odbioru rzeczywistości. Najciekawszą realizacją tematu wydaje się powieść Stanisława Lema Solaris, w której ludzkość próbuje komunikować się z gigantycznym oceanem plazmy, a więc istotą skrajnie od ludzkości różną. Inny problem sygnalizują bracia Strugaccy w książce Piknik na skraju drogi - tytuł jest metaforą opisującą różnicę potencjałów kulturowych między obcą cywilizacją a homo sapiens. Inne intrygujące pytanie - jakie konsekwencje metafizyczno-teologiczne niesie ze sobą kontakt z obcymi cywilizacjami; pojawia się problem „protezowania metafizyki” w literaturze fantastycznej (czyli zastępowania cudowności technologią, Boga - figurą wszechmocnego technologicznie obcego).
\end{abstract}

Słowa kluczowe: science fiction, obcy, konflikt wartości, dramat poznawczy, protetyka metafizyczna

1. Uwagi wstępne. 2. Konsekwencje metafizyczne. 3. Konsekwencje epistemologiczne. 4. Konsekwencje aksjologiczne. 5. Uwagi końcowe.

\section{UWAGI WSTĘPNE}

Literatura fantastycznonaukowa od wielu dekad przedstawia wizje życia rozumnego na innych, spełniających oczywiście po temu odpowiednie warunki, planetach. W przeważającej większości jest to literatura awanturnicza, pozbawiona wysokich wartości intelektualnych, a rozważany tam wariant spotkania obcych sobie istot występuje $\mathrm{w}$ wersji silnie antagonistycznej - kreśli się i powiela warianty znane $\mathrm{z}$ historii gatunku homo sapiens, czyli strategie konkwistadorskiego 
podboju (jedynym zróżnicowaniem jest „kto kogo” - czy obce rasy pacyfikują ludzkość, czy też raczej odwrotnie). Są jednak autorzy (wymienić należy w tym gronie Stanisława Lema, Jacka Dukaja, Philipa K. Dicka, Arkadija i Borysa Strugackich - lista nie jest wyczerpana), którzy podejmują tematykę obcości w kontekście wielopłaszczyznowych rozważań jej filozoficznych konsekwencji.

Niestrudzony egzegeta twórczości Stanisława Lem, profesor Jerzy Jarzębski, dostrzega ewolucję motywu obcości w literaturze science fiction-od ujęć prymitywnych i oczywistych do realizacji subtelnych i bardziej intelektualnie wyrafinowanych. „Kreacje Obcych - pisze Jarzębski - ewoluowały na przestrzeni dziesięcioleci czy stuleci równolegle do ewolucji problematyki kontaktu. W fantastyce pierwotnejtej, która natchnienie czerpała jeszcze z mitologii - istoty myślące zasadniczo od ludzi odmienne nie dawały się jeszcze pomyśleć. (...) W pierwszych powieściach, które moglibyśmy zaliczyć do science fiction, a które wprowadzają do fabuły postacie Obcych, króluje z kolei antropomorfizm: niezależnie od wyglądu zewnętrznego i miejsca zamieszkania istoty pozaziemskie zachowują się i myślą podobnie do ludzi. Dopiero w ostatnich dziesięcioleciach pojawiają się próby wykoncypowania cywilizacji czy istot zasadniczo ahumanistycznych, przy których opisie ziemskie kategorie nie wystarczają, a kontakt napotyka przeszkody trudne lub niemożliwe do pokonania"1.

Pisarze tacy jak Dukaj, Lem, Strugaccy - w ramach szeroko pojętej tematyki epistemologicznej - zadają pytanie o możliwość porozumienia $z$ intelektem rozwiniętym $w$ środowisku skrajnie od ludzkiego różnym, wyposażonym przy tym w zupełnie odmienny aparat percepcji rzeczywistości. Odpowiedzi z reguły mają wydźwięk silnie pesymistyczny.

Obok zagadnień epistemologicznych motyw napotkania obcości w literaturze science fiction jest również pretekstem do rozważań metafizycznych czy też teologicznych. Zachodzi tu ciekawe zjawisko

1 J. Jarzębski, Wszechświat Lema, Kraków 2002, 212. 
swoistego „protezowania metafizyki”, zastępowania cudowności technologiczną mocą, Boga - figurą obcej istoty, „wszechmocnej” dzięki przewagom nadzwyczajnej techniki. W tym nurcie mieści się powieść Solaris (1961) Stanisława Lema, gdzie po raz pierwszy pojawia się motyw „kalekiego boga”, przewijający się przez późniejszą twórczość pisarza.

Interesujące „pole doświadczalne” stanowi także wpływ istnienia mniemanych obcych cywilizacji na zmianę ludzkiego systemu wartości. Czy możliwy jest transfer obcego sposobu wartościowania, być może opartego na zupełnie różnych zasadach?

Zacznijmy od konsekwencji teologicznych i metafizycznych, jakie niesie ze sobą tematyka kontaktu międzycywilizacyjnego.

\section{KONSEKWENCJE METAFIZYCZNE}

Autorzy literatury science fiction traktują zwykle motywy metafizyczne w sposób specyficzny - transponują je bowiem na język paranaukowy. W swym szkicu poświęconym motywom metafizycznym w polskiej literaturze fantastycznej Tadeusz Olszański dostrzega taką oto prawidłowość: „Nowoczesna literatura fantastyczna, której fundatorami są Verne i Wells, od początku przyjęła perspektywę laicką (agnostyczną lub wręcz ateistyczną) i zgodnie $\mathrm{z}$ nią opisywała świat taki, jakby nie było w nim nie tylko Boga, ale także jakiejkolwiek transcendencji. Działo się tak nawet wówczas, gdy autorzy opisywali funkcjonowanie wyobrażeń i organizacji religijnych"2. Z kolei teoretyk fantastyki, Darko Suvin, twierdzi, że „konceptualny zrąb nauki stanowiący podstawę literatury fantastycznonaukowej wyklucza jakiekolwiek flirty z religią"

2 T. A. Olszański, Mesjasz i Szatan w najnowszej fantastyce polskiej, Nowa Fantastyka (1994)4, 65.

3 Podaję za: T. Woodman, Science fiction, religia i transcendencja, tłum. z ang. B. Okólska, w: Spór o SF, red. R. Handke, L. Jęczmyk, B. Okólska, Poznań 1989, 399. Oczywiście i w literaturze science fiction - obok sceptyków i „protetyków” - zdarzają się rasowi 
Zarazem jednak twórcy fantastyki naukowej, kreując światy nierzeczywiste, odczuwają - jak ujął to znakomity tłumacz i teoretyk literatury science fiction Lech Jęczmyk - swoistą „dziurę metafizyczną”, pustkę po nieobecnym Bogu, „lej” pozostawiony po „teologicznej eksplozji” (czy też może implozji), której zasięg rozszerzał się wraz z ekspansją paradygmatu scjentologicznego. Wydaje się, że pisarze zajmujący się tematyką usiłują ową wyrwę zasklepić, skonstruować teologiczną „protezę”. Stąd bierze się figura „boga podmienionego" rolę ,zamiennika metafizycznego" pełni w tym wypadku Obcy o mitologicznych właściwościach.

W apokryficznej noweli Stanisława Lema zatytułowanej Nowa Kosmogonia, a stanowiącej część interesującego zbioru recenzji i przedmów do dzieł nigdy niepowstałych (Doskonała próżnia), ukazani są Obcy, których zaawansowanie cywilizacyjne prokuruje niemal boskie możliwości kreacyjne. Przedstawia tu autor (w formie przemówienia wybitnego astronoma Alfreda Testy, postaci, rzecz jasna, fikcyjnej) radykalną wizję koncepcji wszechświata. W świetle tej hipotezy

metafizycy, jak Clive Staples Lewis czy Philip K. Dick. Ten ostatni, niezwykle interesujący pisarz amerykański, odnajdywał akcenty metafizyczne w pstrokaciźnie, codzienności i zwyczajności otaczającego nas świata. Bogiem (złym demiurgiem?) może się w jego twórczości okazać sonda kosmiczna obcej cywilizacji, jak ma to miejsce w powieści Valis. W tej samej powieści pojawia się po raz pierwszy „Zasada Zebry” jako pojęcie określające istotę boskości. Dick wysnuł ową zasadę z obserwacji zjawiska mimikry u owadów i innych zwierząt (zebr właśnie) potrafiących upodabniać się do części roślin. Pisarz amerykański postuluje mimikrę wyższego rzędu, czyli Boga, który przebywa wprawdzie pośród ludzi, lecz jest zupełnie niedostrzegalny, ponieważ kryje się za rzeczami codziennego użytku. Stąd wynika imperatyw bohaterów Dicka - poszukiwań boskości w codzienności, absolutu w banale. W innej jego powieści (Ubik) absolut mieści się W... spreju. Bohaterowie egzystują w rzeczywistości rozpadającej się, podległej procesowi entropii, której przeciwdziałać może wyłącznie tytułowy „ubik”, czyli absolut aplikowany w spreju. Twórczość Philipa K. Dicka stanowi jednak pewną anomalię, wyjątek w regule racjonalności pozytywistycznej i naturalistycznej literatury fantastycznonaukowej.

4 Określenie to występuje w eseju Macieja Parowskiego opisującym strategie unikania (bądź zastępowania) tematyki metafizycznej w literaturze science fiction. Por. M. Parowski, Boże igrzyska, w: tenże, Małpy Pana Boga, Warszawa 2011, 86-92. 
kosmos - wraz z nieznanymi lub nie do końca wyjaśnionymi fenomenami (czarne dziury, kwazary itp.) - byłby w większej części tworem sztucznym, jako wynik swoistego „kompromisu” kilku supercywilizacji. Porozumienie ma charakter wielostronny - rzeczone supercywilizacje wytworzyły w powolnym, lecz monstrualnym procesie, $\mathrm{w}$ swoim własnym dobrze pojętym interesie, nieistniejący przedtem porządek i prawa, które dziś ludzkość poznaje i uważa - błędnie - za naturalne, wieczne i majestatyczne prawa natury. Dawniej rządzić miały światem inne prawa fizyczne, które różniły się między sobą w zależności od strefy kosmosu. Przykładem niech będzie prędkość światła, która kiedyś nie stanowiła bynajmniej powszechnie nieprzekraczalnej granicy. Tymczasem supercywilizacje, zdobywszy wiedzę naukową i technologiczną z ludzkiego punktu widzenia niewyobrażalną, odkryły wzajem swoje istnienie i rozpoczęły po dziś dzień trwającą grę, do której automatycznie przyłącza się każda cywilizacja wystarczająco rozwinięta, by wziąć w niej udział. Na przestrzeni miliardów lat - po spowodowaniu niewyobrażalnych katastrof - wytworzono wreszcie wspólnym wysiłkiem jednolity kosmos, w którym prawa fizyki są wszędzie jednakie. Owo kosmiczne status quo wymaga, aby wszechświat był odtąd rządzony przez surową regułę czasoprzestrzeni, wraz z barierą światła, która z kolei sprawia, że komunikacja - po przekroczeniu określonego dystansu - staje się praktycznie niemożliwa.

W opinii Testy, monstrualni gracze, kierowani poczuciem własnego bezpieczeństwa, sami dali milczące przyzwolenie na wykopanie między nimi przepaści komunikacyjnej, co, swoją drogą, tłumaczyć ma tajemnicę silentium universi. $Z$ tych to właśnie powodów praktycznie nierozróżnialne jest we „współczesnym” wszechświecie to, co „naturalne”, oraz to, co „sztucznym” się jawi. Dodatkowo proces gry pobudza bezwiednie negentropię - sprzyja eksplozjom życia w różnych miejscach uniwersum; może zatem się zdarzyć, że ryzykowna gra doprowadzi w końcu do zniszczenia wszechświata, jeśli na przykład przyłączą się do niej przedwcześnie cywilizacje nie dość 
dojrzałe. Kiedy zaś wszystko już powróci do stanu początkowego chaosu, po eonach pojawi się nowa grupa graczy - i porządkowanie zacznie się od nowa. W takim wypadku nie może być mowy o rzeczywistym początku wszechświata - wszystko płynie, a zmienności mają charakter periodyczny, jak w systemie ontologicznym Heraklita; jednak porządkującą rolę logosu pełnią w tym wypadku wysoko rozwinięte cywilizacje.

Niepokojąca w tej wizji jest ontologiczna „piętrowość” kreacji, zdająca się ciągnąć ku nieskończoności - stwórcy znanego kosmosu zostali stworzeni przez innych, tamci być może podobnie - $\mathrm{i}$ tak dalej. Obraz świata składa się tu na monstrualny palimpsest - warstwy ontologicznych korekt nakładają się na siebie, tworząc ciąg nieskończony.

Piętrowość rzeczywistości równie dobitnie jest akcentowana w książce Adama Wiśniewskiego-Snerga Robot. Model kontaktu między cywilizacjami, jaki został w tej powieści nakreślony, określany jest mianem „kontaktu konsumpcyjnego”. Jak to zwykle w fantastyce naukowej bywa, opisana jest tu sytuacja przynajmniej niecodziennaoto część powierzchni naszej planety wraz z zamieszkującymi ten obszar ludźmi, zostaje niejako „pobrana” przez Obcych jako - prawdopodobnie - materiał badawczy.

„Tragedia - mówi jeden $z$ bohaterów powieści Wiśniewskiego-Snerga - polega na tym, że my dla nich nie jesteśmy żadnymi partnerami. Oni nie są przyjaźnie ani wrogo nastawieni, ale racjonalnie (...). Oni zapewne przewożą na stół konsumpcyjny - opakowane ciałami i wykarmione odpowiednim kultem - nasze umysły nie w zaspokojeniu głodu konsumpcyjnego, ale by nasycić głód wiedzy. Nigdy nie uwierzymy w Nadistoty, ponieważ zbyt silne jest mniemanie, że walka o byt już się pod nami skończyła. Kura, widząc człowieka, też nie zauważyłaby Umysłu”.

Wiśniewski-Snerg przedstawia w swej powieści efekty poznawczego „prześlepienia” - ludzie nie są w stanie dostrzec przejawów

5 A. Wiśniewski-Snerg, Robot, Kraków 1973, 351. 
działalności owych Nadistot (poza tymi oczywistymi, czyli wyrwaniem połaci naszej planety w celach, być może, badawczych) - zbyt wielka jest skala ich oddziaływań, motywacja zaś - niedocieczona.

Jeszcze bardziej radykalną wizję kontaktu „niespełnionego” (czy też może wręcz niemożliwego) przedstawia Stanisław Lem na kartach utworu już tu przywoływanego, czyli Solaris. Głównym „bohaterem" utworu jest gigantyczny ocean plazmy oblewający odległa planetę odkrytą przez ludzkość. Występuje w tej powieści motyw intensywnie reprezentowanej w twórczości Lema „różnicy epistemologicznej”, zupełnego braku zrozumienia między podmiotami kontaktu. Ocean - niczym kaleki bóg - przejawia zdolności kreacji; na ziemskiej stacji badawczej zainstalowanej na orbicie wokół obcej planety pojawiają się tzw. twory-F, czyli niezniszczalne materializacje podświadomych lęków (dawno zmarłe osoby itp.). Mieszkańcy stacji zadają sobie (i pośrednio czytelnikom) znaczące pytania: czyżby jedyny mieszkaniec planety Solaris okazał się złośliwym demiurgiem, czyniącym $z$ wyprawy badawczej piekło, nie na Ziemi tym razem, a na Solaris? Wprawdzie sam Stanisław Lem deprecjonował metafizyczne wykładnie swej powieści, pisząc: „Solaris nie ma nic wspólnego z metafizyczną problematyką, wręcz odwrotnie nawet: »niemożliwość«metafizyki, w sensie - transcendencji, jest tej powieści założeniem. »Cuda«, jakie na stacji Solaris czyni ocean, są tylko skrajnie mało prawdopodobnymi, lecz zasadniczo możliwymi fenomenami o materialnym charakterze" ${ }^{1}$. Wydaje się jednak, że jeśli nawet zasadniczo materialistyczna wykładnia fenomenów pro-

6 S. Lem, Fantastyka i futurologia, t. 2, Kraków 1989, 217. Nieco żartobliwie, by nie powiedzieć krotochwilnie, pisze Lem o kłopotach z tematyką teologiczną w fantastyce w Podróży 22, zawartej w słynnych Dziennikach gwiazdowych. W opowiadaniu tym znany galaktyczny podróżnik Ijon Tichy rozmawia z zakonnikiem ojcem Lecymopem, który żali się na swe rozliczne trudności w kosmicznej pracy misyjnej. A to z tego powodu, że np. rasa Pięciorniaków żyjących w temperaturze powyżej sześciuset stopni Celsjusza, marzy o piekielnych ogniach. Bżutowie zaś, zdolni powstawać z martwych, nie pojmują nadzwyczajności Ewangelii oraz doniosłości jej wymowy. Mnemongowie z kolei, których nawrócił ojciec Obrazy, powodowani ogromną wdzięcznością, umożliwili mu śmierć 
kurowanych przez Obcego ma charakter - w powieściowej ontologii - obiektywny, to pozostaje jeszcze subiektywny ich odbiór przez powieściowych badaczy, mocno przecież zabarwiony rozważaniami teologicznymi. Do pewnego stopnia z autorską wykładnią polemizuje także Fredric James, pisząc: „A jednak pozostaje przecież możliwość, że Solaris jest podobnie ułomną istotą jak my - ułomnym bądź schorzałym bogiem, podobnym do szalonego bóstwa u Schellinga, które stworzyło świat po to, by się wyleczyć”" Zresztą na kartach powieści pojawia się pogląd, że solarystyka (czyli nowa gałąź wiedzy - nauka o Solaris) może być traktowana niemal jak światopogląd religijny. „Solarystyka... jest namiastką religii wieku kosmicznego, jest wiarą przyobleczoną w szatę nauki; kontakt, cel, ku któremu dąży, równie jest mglisty i ciemny, jak obcowanie świętych czy zejście Mesjasza. Eksploracja to w metodologicznych formułkach egzystująca liturgia, pokorna praca badaczy jest oczekiwaniem spełnienia, Zwiastowania, albowiem nie ma i nie może być mostów między Solaris a Ziemią"8.

męczeńską. Mieszkańcy planety Arpetuza wreszcie tak przejęli się nakazem powszechnej czystości, że w ogóle przestali się rozmnażać, ich populacja zaś wyginęła.

7 F. Jameson, Archeologie przyszłości. Pragnienie zwane utopia i inne fantazje naukowe, tłum. z ang. M. Płaza, M. Frankiewicz, A. Miszk, Kraków 2011, 134-135. Jerzy Jarzębski uważa, że motyw „kalekiego boga” jest jednym z ulubionych tematów w twórczości Stanisława Lema. Pierwszy raz używa pisarz tego określenia właśnie w Solaris, jednak pełniejszy wymiar koncept ten osiąga w utworach późniejszych. Idzie tu - jak opisuje to Jarzębski - o „wizję nieciągłej hierarchii światów i Rozumów. Gdzie Rozum wyższy - jako kreator i opiekun niższej postaci bytów myślących - byłby od nich oddzielony barierą dla nich nieprzebytą, sam jednak zachowałby możliwość ograniczonego wpływania na ich życie". Por. J. Jarzębski, dz. cyt., 145.

8 S. Lem, Solaris, Kraków 1961, 166. Uderza w tych fantastycznych ujęciach problematyki kontaktu z obcymi rozumami pewne, na pierwszy rzut oka odległe, ale jednak podobieństwo. Otóż owa nadrzędność i nieopisywalność Obcych przywodzi na myśl, przy zachowaniu odpowiednich proporcji, teologię apofatyczną neoplatoników (Klemensa Aleksandryjskiego, Pseudo-Dionizego Areopagity), którzy przecież odrzucali - podobnie jak badacze Solaris - wszelkie symbole, obrazy i abstrakcyjne pojęcia, jako nieprzystające, nieadekwatne do opisu nieopisywalnego. 
Inne istotne pytania, jakie zadaje Lem w swojej powieści (kto tu kogo bada? czy solaryczny ocean kreuje twory- $\mathrm{F}$ w celach poznawczych? czy jest istotą samoświadomą? czy można tu mówić o świadomości w ludzkim tego słowa rozumieniu?), odsyłają nas w sferą zagadnień epistemologicznych.

\section{KONSEKWENCJE EPISTEMOLOGICZNE}

Manfred Geier uważa Solaris za znakomitą egzemplifikację problemów z zakresu filozofii języka. Niepodległość rzeczonego oceanu jakimkolwiek zabiegom eksperymentalnym oznacza tyle, że znak językowy, wyrażający jakieś ogólne zjawisko lub reakcję, nie może oddać w żaden sposób rzeczywistości oceanu; ten bowiem nie dopuszcza do iteracji wyników. Poza tym ludzie przez „okulary” swego znaczącego języka potrafią przyjmować do wiadomości jedynie te fragmenty rzeczywistości, które są im znane dzięki powtarzalnemu doświadczeniu własnego świata, a „ocean jako egzystencja obca jest dla nich bezwarunkowo niepojmowalny"'. Jak ujmuje to jeden $\mathrm{z}$ bohaterów powieści Lema: „Mamy się za rycerzy Świętego Kontaktu. (...) Nie szukamy nikogo oprócz ludzi. Nie potrzeba nam innych światów. Potrzeba nam luster... Chcemy znaleźć własny, wyidealizowany obraz... Tymczasem po drugiej stronie jest coś, czego nie przyjmujemy, przed czym się bronimy, a przecież nie przywieźliśmy z Ziemi tylko destylatu cnót"10.

Lem rysuje sytuację, w której badający rzeczywistość uczeni znajdują się - jak opisuje to Alina Motycka - „w poznawczym punkcie zerowym i niejako sam na sam $z$ narastającymi anomaliami, wobec których zastana teoria staje się bezradna. (...) Bezużyteczna okazuje

9 M. Geier, Fantastyczny ocean Stanisława Lema (Przyczynek do semantycznej interpretacji powieści »Solaris«), tłum. z niem. R. Wojnarowski, w: Lem w oczach krytyki światowej, red. J. Jarzębski, Kraków 1989, 168.

10 S. Lem, Solaris, 71. 
się również zdolność podmiotu zwana rozumem (a więc ten doskonały zestaw schematów i procedur demonstratywnych), którą to uczony wprawdzie posiada, ale w sytuacji tu opisanej nie ma jej do czego użyć. Jest to więc sytuacja poznawcza, którą filozofowie nauki nazywają kryzysem, a egzystencjaliści (za Karlem Jaspersem) nazwaliby ją "sytuacją graniczną" $" 11$.

Podobne trudności natury epistemologicznej ukazuje w swej interesującej powieści zatytułowanej Ślepowidzenie Peter Watts. W fabule tej opowieści ludzkość na drodze swej kosmicznej ekspansji napotyka zadziwiająca rasę tzw. Wężydeł, istot, których poszczególni przedstawiciele pozbawieni są samoświadomości, lecz tworzą - być może (tryb przypuszczający, podobnie jak w utworach Stanisława Lema, jest tu nieodzowny, mniemania na temat obcych istot mają charakter spekulacji i hipotez) rodzaj świadomości kolektywnej. Skuteczność i niespotykana szybkość reakcji i działań Wężydeł budzi poważne obawy członków ziemskiej misji badawczej. Rodzi się w nich również ten rodzaj autorefleksji, który bezpowrotnie burzy dobre samopoczucie przedstawicieli gatunku homo sapiens. Bowiem czy ludzka samoświadomość, zdolność do myślenia abstrakcyjnego, istotnie jest atutem, czy też raczej balastem w konfrontacji z przeciwnikiem (? - i w tym wypadku znak zapytania wydaje się nieodzowny; zamiary obcych istot raz jeszcze okazują się niedocieczone) tak bardzo przewyższającym ludzi np. szybkością reakcji w sytuacji kryzysowej?

Tymczasem ludzką świadomość oraz jej „wydolność” percepcyjną opisuje Watts następująco: „Układ słabnie i spowalnia. Postrzeganie

11 A. Motycka, Czynności poznawcze a epistemologia, w: Epistemologia współcześnie, red. M. Hetmański, Kraków 2007, 112. Dalej (na tej samej stronie) Motycka pisze: „Uczony w sytuacji chaosu, jaki narasta w nauce kryzysowej i wobec którego jest bezradny (...), dokonuje zwrotu (regres) ku treściom, które nie są wyrażone w języku nauki, lecz przynależą do porządku myślenia mityczno-metafizycznego. Sama zaś czynność (regres) nie mieści się w żadnych racjonalnych standardach postępowania naukowego, nie jest wyznaczona przez żadną procedurę rozumu naukowego ani też świadomie planowana przez uczonego, który traktuje ją raczej jako swoistą ucieczkę (...)”. Opis ten znakomicie pasuje do zachowań naukowców badających Solaris. 
trwa teraz o wiele dłużej - trzeba ocenić dane wejściowe, podumać nad nimi, podjąć decyzję, jak robią to świadome istoty. Lecz kiedy widzisz nagłą falę wody, albo z trawy wyskakuje na ciebie lew, wypasiona samoświadomość to luksus, na który cię nie stać. Najlepiej sprawdza się pień mózgu. Dostrzega niebezpieczeństwo, przejmuje ciało i reaguje sto razy szybciej niż ten stary tłuścioch $\mathrm{w}$ fotelu prezesa na piętrze; ale $z$ każdym kolejnym pokoleniem coraz trudniej jest to obchodzić - tę skrzypiącą neurologiczną biurokrację. Ja marnuje energię i moc przetwarzania, obsesyjnie, aż po psychozę, skupione na samym sobie. Wężydła go nie potrzebują, Wężydła są oszczędniejsze. $Z$ prostszą biochemią, z mniejszym mózgiem, pozbawione narzędzi, nawet części własnego metabolizmu - myślą, a ty nie dorastasz im do pięt. Ukrywają swój język przed tobą, rozmawiają przed twoim nosem. (...) Umieją obrócić przeciwko tobie twoje własne postrzeganie. Podróżują do gwiazd. Oto, co potrafi nieobciążona samoświadomością inteligencja” ${ }^{12}$. I w innym miejscu: „Wyobraź sobie, że jesteś Wężydłem. Wyobraź sobie, że masz intelekt, ale żadnego zrozumienia, masz plany, ale nie świadomość. W twoich obwodach szemrzą strategie przetrwania osobniczego i gatunkowego, elastyczne, inteligentne, nawet korzystające $z$ technologii, ale nie monitoruje ich żaden inny układ. Możesz pomyśleć o wszystkim, ale niczego nie jesteś świadom. Nie da się wyobrazić sobie czegoś takiego, prawda? Nawet sam termin istota w jakiś niejasny, ale fundamentalny sposób nie pasuje"13.

Trzeba przyznać, że potężniejszej dekonstrukcji wysokich mniemań o intelektualnych przewagach gatunku bomo sapiens nie było od dawna - skoro źródło naszych największych ewolucyjnych sukcesów, czyli samoświadoma inteligencja, okazuje się balastem poznawczym i źródłem dotkliwych pomyłek i porażek.

12 P. Watts, Ślepowiedzenie, tłum. z ang. W. M. Próchniewicz, Warszawa 2008, 257-258.

13 Tamże, 275. 
Chwieje paradygmatem antropocentrycznym również wymowa powieści braci Strugackich Piknik na skraju drogi. Oto w kilku punktach - symetrycznie od siebie oddalonych - naszego globu dochodzi do lądowania obcych statków kosmicznych. Do kontaktu z przedstawicielami ziemskiej cywilizacji nie doszło, natomiast po Obcych zostały tzw. strefy, czyli obszary zadziwiających fenomenów, przeczących prawom znanej nam fizyki. Strefy dostarczają ludzkości różnego rodzaju „gadżetów”, których właściwe przeznaczenie czy też sposób działania przerasta dostępną nam wiedzę. Różnica poziomów rozwoju jest tak potężna, że zasadnym wydaje się sposób tłumaczenia zachowania Obcych poprzez metaforę zawartą w tytule powieści Strugackich. Obcy wylądowali na naszej planecie przypadkowo, być może nawet nie dostrzegli ludzi i przejawów ich działalności. Rozbili piknik na skraju galaktycznej drogi; pozostawili po sobie różnego rodzaju resztki, śmieci, zużyte baterie, puste butelki, które są następnie „badane” $i$,eksplorowane” przez nieznające ich właściwego zastosowania... mrówki. W roli pracowitych owadów są w tej metaforze obsadzeni oczywiście ludzie - co ma podkreślić ontologiczną i epistemologiczną przepaść między Obcymi i ludźmi.

Największą - nie da się chyba inaczej tego określić - desperację poznawczą prezentują bohaterowie noweli Jacka Dukaja Szkota. I znów ludzie, podczas swej śmiałej eksploracji dalekiego kosmosu, natykają się na Obcych, zupełnie różnych pod względem biologicznym. Przypuszcza się, że procesy percepcji rzeczywistości przebiegają u tych istot na zupełnie innym poziomie niż u ludzi. Wszelkie próby porozumienia spełzają na niczym; cywilizacyjny konflikt na ogromną skalę wydaje się nie do uniknięcia. Ziemianie podejmują radykalną próbę nawiązania kontaktu - mianowicie „bioformują” jednego z przedstawicieli własnego gatunku, czyli przeistaczają go w formę życia jak najbardziej zbliżoną do postaci Obcych. Opisy stanów wewnętrznych transformowanego stopniowo człowieka ocierają się o granice języka, co było, rzecz jasna, autorskim zamiarem Dukaja. W noweli poruszane są kwestie filozoficznie istotne - pytanie 
o granice człowieczeństwa, o zasadność tak daleko posuniętych roszczeń poznawczych gatunku homo sapiens. Wątpliwość natury moralnej budzi zasadność tak radykalnego eksperymentu (pomijając nawet jego wymiar czysto pragmatyczny - czy bowiem ów człowiek-nieczłowiek będzie w ogóle $\mathrm{w}$ stanie zdać relację z kontaktu, jeśliby do niego doszło?) - czy interes gatunku równoważy na szali aksjologicznej wagi cierpienia jednostki? Wkraczamy tym samym na kolejny obszar rozważań filozoficznych konsekwencji kontaktu z obcymi rozumami - konsekwencji aksjologicznych i etycznych.

\section{KONSEKWENCJE AKSJOLOGICZNE}

Zderzenia cywilizacyjne występujące na kartach literatury science fiction są opisem nie tylko konfrontacji technologicznych mocy, ale również systemów wartości ludzi oraz Obcych. Częstym motywem występującym w tego typu twórczości jest obojętność przedstawicieli obcych kultur wobec ludzkich dokonań cywilizacyjnych, czy też ludzkich systemów wartości. Wspomnijmy bezduszny pragmatyzm wellsowskich Marsjan (Wojna śrwiatów), niemal „boską” nadrzędność Nadistot Wiśniewskiego-Snerga (Robot), ontologiczną przewagę „kalekich bóstw” z utworów Lema i Dicka, obecność kosmitów ponad lub poza możliwościami naszej percepcji, implikująca ich obojętność wobec faktu istnienia ludzkości (Piknik na skraju drogi Strugackich). Przepaść statusów jest równoznaczna z brakiem równowagi aksjologicznej - cóż bowiem oznacza „moralna słuszność” wobec technicznej możliwości porwania przez Obcych całego miasta wypełnionego ludzką populacją i uczynienie $z$ niego gigantycznego laboratorium behawioralnego, jak miało to miejsce w przywoływanej powieści Wiśniewskiego-Snerga.

Ukazanie ludzkości na tle innych kultur kruszy niewątpliwie postawę antropocentryczną, sprzyja relatywizmom etycznym. Autorzy literatury fantastycznonaukowej podejmują próbę wyobrażenia sobie sposobu odbioru świata przez obce istoty, próbują symetrycznie 
„rozdawać racje” w wyimaginowanych konfliktach, innymi słowy, przyjmują obcy punkt widzenia.

Nieco żartobliwą ilustracją tej tezy może być krótkie opowiadanie H. B. Fyfe'a zatytułowane Satata i brylant - mamy tu kanonicznie do pewnego momentu rozegrany motyw kontaktu ludzkości z obca cywilizacją; na galaktycznych rubieżach spotykają się dwa statki kosmiczne - wypełnione ludzką i nieludzką załogą. Obie strony rychło przekonują się, że ich obcy partnerzy posiadają - jakże z ich punktu widzenia pożądane - technologie. Obcy potrafią syntetyzować ciężkie pierwiastki, w tym na przykład złoto, co ze zrozumiałych względów budzi żywe zainteresowanie Ziemian. Kosmici z kolei zazdroszczą ludziom technologii uprawy roślin w trudnych warunkach kosmicznych. Dochodzi do wymiany technologii, po czym oba statki kosmiczne umykają z miejsca spotkania pełną mocą silników - każda ze stron przekonana jest bowiem, że udało jej się oszukać tę drugą. „Cenność” okazuje się z tego punktu widzenia wartością relatywną, zmienną, silnie uzależnioną od punktu widzenia.

Ludzcy bohaterowie fantastycznych opowieści, w obliczu kontaktu z obcą cywilizacją, stają wobec sytuacji, delikatnie rzecz ujmując, niecodziennej, wymykającej się prostym kodyfikacjom moralnym, nieprzystającym do ich doświadczenia aksjologicznego. Przyjmują zatem w większości wypadków, mniej lub bardziej świadomie, postawę przypominającą główne postulaty etyki sytuacyjnej Josepha Fletchera, oczywiście zmodyfikowane na potrzeby kosmicznych konieczności. Fletcher wskazywał na bezsilność wielkich systemów etycznych wobec postępującej zmienności rzeczywistości wywołanej przemianami cywilizacyjnymi. Robocze zasady (ponieważ i sytuacjonizm, jak się okazuje, bez zasad obejść się nie może) to: zasada pragmatyzmu (by czyn był słuszny, musi być skuteczny), zasada relatywizmu (unikanie szerokich kwantyfikatorów w twierdzeniach normatywnych, typu „nigdy”, „zawsze”, „każdy”) oraz zasada personalizmu (ludzie, ich życie, istnienie, integralność, są istotniejsi od jakichkolwiek zasad). 
Ciekawą ilustracją sytuacji wymykającej się jednoznacznym kwalifikacjom moralnym jest ta zarysowana w opowiadaniu Myślé jak Dinozaury amerykańskiego pisarza Patricka Kelly'ego. Tytułowe Dinozaury to gadzia odmiana obcych istot, których cywilizacja znacznie bardziej jest zaawansowana technologicznie niż ludzka. Dinozaury opanowały między innymi niezwykle pożądaną przez ludzi technologię transferu materii ożywionej (a więc $\mathrm{i}$ istot żywych) na galaktyczne wręcz odległości. W tym celu osobnik przesyłany jest dokładnie kopiowany („do ostatniego atomu”), a następnie rozbijany na cząsteczki i przesyłany w jednej chwili na dowolną odległość. Procedury kopiowania są zapewne wyrazem przezorności Dinozaurów - na wypadek niepowodzenia transferu. Częścią procedury - utrzymywaną przez Obcych w ścisłej tajemnicy - jest fakt natychmiastowego unicestwienia „oryginału” - wynika to z przekonania Dinozaurów o konieczności zachowania „kosmicznej równowagi” (we wszechświecie nie powinny wspólistnieć istoty o identycznym wyposażeniu strukturalnym i świadomościowym). Rzecz jasna, transferowany osobnik nie zdaje sobie sprawy z tego, że czeka go śmierć.

Głównym bohaterem tekstu Kelly'ego jest człowiek, który asystuje Dinozaurom w ich transferowych operacjach. W trakcie jednej z nich dochodzi do fatalnej pomyłki - wysyłany człowiek zostaje zachowany w dwu tożsamych postaciach. Obcy - pozostając w zgodzie ze swymi zasadami - żądają od ludzkiego asystenta likwidacji owego ontologicznego "nadmiaru” istnienia. Ten, mimo oczywistych oporów natury moralnej, przystaje na to - w imię przyszłych korzyści płynących z cywilizacyjnej kooperacji. Jest to intrygujący przykład znów swoistego „transferu”, ale tym razem systemu wartości - oto przedstawiciel gatunku homo sapiens przyjmuje za własną obcą optykę aksjologiczną. Człowiek, wbrew np. kantowskiej etyce, przestaje stanowić cel sam w sobie, a staje się środkiem wiodącym ku celom rozleglejszym. Można by zinterpretować opowiadanie Kelly'ego paradoksalnie - pojawia się bowiem w fabule tekstu taka sytuacja, która zupełnie odwraca wskazania etyki sytuacyjnej. To nie człowiek 
okazuje się ważniejszy od zasad, lecz zasady - dyktowane interesami naszego gatunku - wydają się istotniejsze od partykularnych korzyści jednostek.

Na zakończenie rozważań, dotyczących konsekwencji aksjologicznych wynikłych ze spotkań z obcością, warto przytoczyć cenną uwagę Macieja Płazy z jego monografii poświęconej zagadnieniom epistemologicznym w prozie Stanisława Lema. Pisząc o częstym przez Lema podejmowanym temacie kontaktu, Płaza dostrzega ciekawą prawidłowość - otóż w większość kosmicznych wypraw polski pisarz wysyła lekarzy, zaś przyświecająca ich działalności zasada primum non nocere wydaje się ,jedyną uniwersalną zasadą etyczną, która zachowuje ważność we wszystkich możliwych do pomyślenia poznawczych dylematach" ${ }^{14}$. Zatem nieszkodzenie, oznaczające często wstrzymanie się od jakichkolwiek działań, jest być może jedyną dopuszczalną postawą w zetknięciu $\mathrm{z}$ absolutną obcością. Bohaterowie takich powieści Lema jak Eden czy Solaris ostatecznie taką właśnie postawę, swoistej neutralności aksjologicznej, przyjmują; jeśli natomiast pozostają przy stanowisku antropocentrycznym, sądząc rzeczywistość „ludzką miarą", ponoszą zwykle dotkliwe klęski - jak miało to choćby miejsce w powieści - znamiennie zatytułowanej - Fiasko.

\section{UWAGI KOŃCOWE}

Oczywiście rodzi się pytanie - czy wizje kosmosu wypełnionego obcymi istotami niosą ze sobą istotne filozoficznie przesłania i znaczenia, czy też owe fantastyczne rojenia okazują się li tylko rozrywką? W swej masie literatura science fiction pełni z pewnością rolę rozrywkowo-eskapistyczną; czytelnik zagłębia się w obce światy, by zapomnieć, choć na czas trwania lektury, o problemach świata realnego. Istnieje jednak taka sfera piśmiennictwa fantastycznego

14 M. Płaza, O poznaniu w twórczości Stanisława Lema, Wrocław 2006, 327. 
(i tym obszarem, niestety znacząco węższym, głównie byłem zainteresowany, pisząc powyższy artykuł), w której autorom chodzi o coś więcej.

Z grubsza można by podzielić funkcje ambitnej literatury „kontaktowej" na dwa segmenty. Po pierwsze, byłaby to funkcja symulacyjna - co by było, gdyby człowiek napotkał obce rozumy, jaki miałoby to wpływ na nasze postrzeganie wszechświata, jakie konsekwencje moralne i religijne miałoby takie zetknięcie? Czy nasza aparatura poznawcza jest $\mathrm{w}$ ogóle przygotowana na podobne fenomeny (wielki temat twórczości Stanisława Lema) ${ }^{15}$. Ambitną, intelektualnie pogłębioną literaturę fantastyczną można traktować jako rodzaj laboratorium, w którym obiektem symulacyjnych penetracji jest umysł czytelnika. Jak zareagujemy na fenomen obcości całkowitej (Solaris Lema, Piknik na skraju drogi braci Strugackich, Szkota Dukaja) - agresją? Wykluczeniem? Wyparciem? Ciekawością? Ucieczką? Paradoksalnie, najbardziej interesujące są te realizacje tematu, które charakteryzują się epistemologicznym pesymizmem, utwory samoograniczające się poznawczymi barierami. „Radosna” twórczość fantastów kreślących bujne, egzotyczne pejzaże obcych planet naznaczona jest bardzo często antropomorfizmem, a także antropocentryzmem.

Drugą istotną właściwością fantastyki zajmującej się obcością jest jej „skłonność” do metaforyzowania rzeczywistości. Być może jest to jej funkcja najistotniejsza. Obce istoty stają się w takich utworach (np. Robot Adama Wiśniewskiego-Snerga czy też wielokrotnie tu przywoływane Solaris Stanisława Lema) rodzajem zwierciadła, w którym przegląda się ludzkość. Jest to ujęcie relatywizujące naszą pozycję w kosmosie, a zarazem funkcje prognostyczne schodzą tu na

15 Literaturą fantastyczną jako obszarem symulacji dylematów moralnych zajmowałem się w mojej monografii, do której odsyłam zainteresowanych. Por. J. Sobota, Konflikty moralne. Literatura fantastycznonaukowa jako próba symulacji sytuacji konfliktowych, Olsztyn 2011. 
plan dalszy ${ }^{16}$. Obcy stanowią dla nas kontrapunkt, interesujący obiekt odniesień i porównań; uwypukleń naszych zalet bądź - częściej wad. Przysztość jest metaforq - jak niegdyś ujęła to celnie znakomita pisarka Ursula K. Le Guin.

\section{BIBLIOGRAFIA}

Dick P. K., Ubik, tłum. z ang. M. Roniker, Wyd. Amber, Poznań 1990.

Dick P. K., Valis, tłum. z ang. L. Jęczmyk, Wyd. Rebis, Poznań 1994.

Dukaj J., Szkota, Wyd. Literackie, Kraków 2015.

Fyfe H. B., Satata i brylant, tłum. z ang. J. Stawiński, w: Rakietowe szlaki, red. J. Stawiński, Wyd. Iskry, Warszawa 1958.

Geier M., Fantastyczny ocean Stanistawa Lema (przyczynek do semantycznej interpretacji powieści „Solaris”), tłum. z niem. M. Wojnarowski, w: Lem w oczach krytyki swwiatowej, red. J. Jarzębski, Wyd. Literackie, Kraków 1989, 142-217.

Jameson F., Archeologie przysztości. Pragnienie zwane utopia i inne fantazje naukowe, tłum. $z$ ang. M. Płaza, M. Frankiewicz, A. Miszk, Wyd. Uniwersytetu Jagiellońskiego, Kraków 2011.

Jarzębski J., Wszechświat Lema, Wyd. Literackie, Kraków 2002.

Kelly P., Myślé́ jak dinozaury, tłum. z angielskiego R. Wilkoński, Nowa Fantastyka (1998)8, 3-8.

Lem S., Dzienniki grwiazdowe, Wyd. Literackie, Kraków 1982.

Lem S., Fantastyka i futurologia, t. 2, Wyd. Literackie, Kraków 1989.

Lem S., Nowa kosmogonia, w: Tenże, Doskonata próżnia, Wyd. Agora, Warszawa 2008. Lem S., Solaris, Wyd. Literackie, Kraków 1961.

Motycka A., Czynności poznawcze w nauce a epistemologia, w: Epistemologia wspótcześnie, red. M. Hetmański, Wyd. Universitas, Kraków 2007, 109-115.

Olszański T. A., Mesjasz i Szatan w najnowszej fantastyce polskiej, Nowa Fantastyka (1994)4, 65-68.

Parowski M., Boże igrzyska, w: Tenże, Matpy Pana Boga. Stowa, Narodowe Centrum Kultury, Warszawa 2011.

16 Osobną kategorię stanowią w literaturze fantastycznonaukowej alegorie polityczne. Fantastyka amerykańska lat 50. ubiegłego wieku przedstawiając krwiożerczych Obcych (np. kanoniczny Władca marionetek Roberta A. Heinleina) metaforyzowała w istocie zagrożenie komunizmem. Na przełomie lat 70. i 80. pojawił się w Polsce nurt tzw. fantastyki socjologicznej, gdzie inwazje obcych istot stanowiły aluzyjną (ze względów cenzuralnych) ilustrację zależności naszego kraju od ZSRR (np. twórczość Janusza A. Zajdla). 
Płaza M., O poznaniu w twórczości Stanistawa Lema, Wyd. Uniwersytetu Wrocławskiego, Wrocław 2006.

Sobota J., Literatura fantastycznonaukowa jako próba symulacji sytuacji konfliktowych, Wyd. Uniwersytetu Warmińsko-Mazurskiego, Olsztyn 2011.

Strugaccy A. i B., Piknik na skraju drogi, tłum. z ros. I. Lewandowska, Wyd. Prószyński i S-ka, Warszawa 2009.

Watts P., Ślepowidzenie, tłum. z ang. W. M. Próchniewicz, Wyd. Mag, Warszawa 2008.

Wells H. G., Wojna światów, tłum. z ang. H. Józefowicz, Wyd. Iskry, Warszawa 1977.

Wiśniewski-Snerg A., Robot, Wyd. Literackie, Kraków 1973.

Woodman T., Science fiction, religia i transcendencja, tłum. z ang. B. Okólska, w: Spór o SF, red. R. Handke, L. Jęczmyk, B. Okólska, Wyd. Poznańskie, Poznań 1989, 399-422.

\title{
LITERARY VISIONS OF INTELLIGENT LIFE IN SPACE AND ITS METAPHYSICAL, EPISTEMOLOGICAL AND AXIOLOGICAL CONSEQUENCES
}

\begin{abstract}
Science Fiction literature described for decades an intelligent form of life on other planets. This scenario raises obvious questions, such as whether we can understand a mind developed in an entirely different environment than our own and equipped with different perceptual capacities. Stanisław Lem's Solaris is perhaps the best realisation of this scenario - a novel where mankind tries to communicate with a giant ocean of plasma, a living organism radically different from human life. Roadside Picnic by the Stugatsky brothers raises another problem exemplified in the title itself, which is a metaphor for potential cultural differences between alien civilisation and homo sapiens. Yet another intriguing question concerns the metaphysical and theological consequences deriving from exchanges with non-human civilisations. There seems to be a problem of 'substitution in metaphysics' in Science Fiction literature (i.e., replace a wonder with technology, or God with technologically almighty aliens).
\end{abstract}

Keywords: science fiction, literature, extraterrestrial life, value conflict, cognitive drama, 'substitution in metaphysics'

\footnotetext{
JACEK SOBOTA

jacek.sobota@uwm.edu.pl

Uniwersytet Warmińsko-Mazurski w Olsztynie, Instytut Filozofii

Kurta Obitza 1, 10-725 Olsztyn

DOI: $10.21697 /$ spch.2016.52.3.14
} 